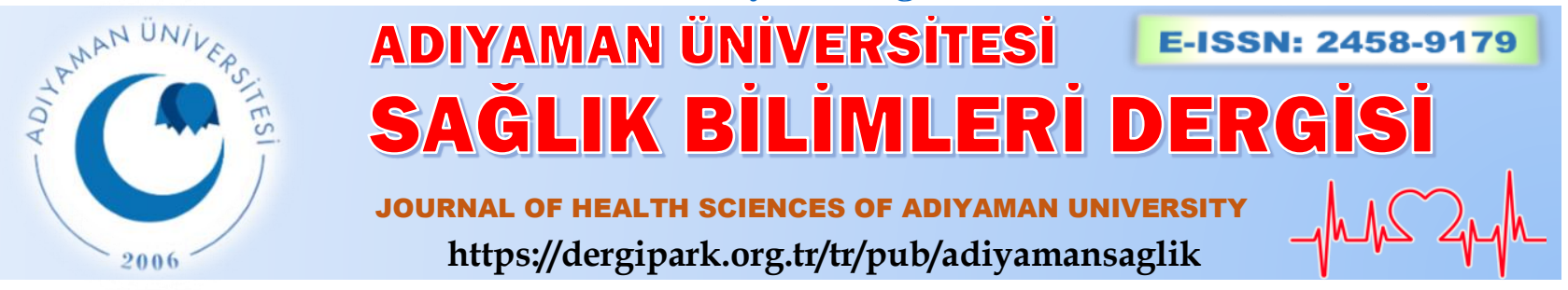

\author{
Özgün Araştırma/Research Article
}

\title{
Hemşirelik öğrencilerinin vakaya dayalı öğretim tekniğine ilişkin görüşleri: nitel bir çalışma
}

\section{Nursing students' views on the case-based teaching technique: a qualitative study}

\author{
Yasemin ALTINBAŞ ${ }^{1}$ (D) Emine DERYA İSTER ${ }^{2 @(D)}$ \\ ${ }^{1}$ Adıyaman Üniversitesi Sağlık Bilimleri Fakültesi, Hemşirelik Bölümü, Cerrahi Hastalıklar Hemşireliği Anabilim Dalı, \\ 02040, Adiyaman-Türkiye \\ ${ }^{2}$ Kahramanmaraş Sütçü İmam Üniversitesi Sağlık Bilimleri Fakültesi, Hemşirelik Bölümü, İç Hastalıkları Hemşireliği \\ Anabilim Dalı, 46040, Kahramanmaraş-Türkiye
}

Atıf gösterme/Cite this article as: Altınbaş Y, Derya İster E. Hemşirelik öğrencilerinin vakaya dayalı öğretim tekniğine ilişkin görüşleri: nitel bir çalışma. ADYÜ Sağlık Bilimleri Derg. 2020;6(3):295-303. doi:10.30569.adiyamansaglik.786162

Öz

Amaç: Bu araştırmanın amacı, Vakaya Dayalı Öğretim tekniği (VDÖ) doğrultusunda planlanan Cerrahi Hastalıkları Hemşireliği dersinde hemşirelik öğrencilerinin vaka sunumları öncesi VDÖ tekniğine yönelik görüşlerinin niteliksel araştırma yöntemi kullanılarak belirlenmesidir.

Gereç ve Yöntem: Kalitatif nitelikteki bu araştırmada 91 öğrenci rastgele örneklem yöntemi yoluyla 13 gruba ayrılmıştır. Her bir öğrenci grubuyla vaka sunumu öncesi yarı yapılandırılmış görüşme formu ile odak grup görüşmesi yapılmış ve görüşme içerikleri betimsel analiz ile değerlendirilmiştir.

Bulgular: Cerrahi hastalıkları hemşireliği dersini alan öğrencilerin VDÖ’ye ilişkin görüşleri 4 ana tema ve 10 alt temada açıklanmıştır. Ana temalar; 1) VDÖ Tekniğine İlişkin Bilgi 2) Grup Çalışması Deneyimi 3) Bir Cerrahi Vakası Sunmak 4) İyi Bir Vaka Sunumu olarak tanımlanmıștır.

Sonuç: Hemşirelik öğrencilerinin eğitiminde VDÖ tekniği ile bilginin daha kalıcı olarak elde edileceği ve bu sürecin onları hemşirelik mesleğine hazırlayacağı ortaya çıkmıştır.

Anahtar Kelimeler: Hemşirelik; Öğrenci; Vakaya dayalı öğrenme.

\begin{abstract}
Aim: The aim of this research is to determine the views of nursing students about CBT technique using the qualitative research method in case of Surgical Diseases Nursing lesson planned in accordance with the Case Based Teaching technique.

Materials and Methods: In this qualitative study, 91 nursing students were divided into 13 groups by random sampling method. A focus group interview was conducted with each group of students before case presentation experience with semi-structured interview form, interview contents were analyzed via descriptive analysis.

Results: The pre-presentation experiences of students reflected in case presentations specific to surgical cases are explained in 4 main themes and 10 sub-themes. Main themes are; 1) Information About CBL 2) Group Work Experience (Facilitators, Difficulties), 3) Presenting a Surgical Case (Advantages, Emotional State), 4) Good Case Presentation (Features of Case Presentation, Student to Present the Case, Source Selection and Expectations).

Conclusion: Nursing students were of the opinion that the knowledge will be obtained more permanently with the CBT technique and this process will prepare them for the nursing profession.
\end{abstract}

Keywords: Nursing; Student; Case-based Learning.

Yazışma Adresi/Address for Correspondence: Emine DERYA İSTER, Kahramanmaraş Sütçü İmam Üniversitesi Sağlık Bilimleri Fakültesi, Hemşirelik Bölümü, İç Hastalıkları Hemşireliği Anabilim Dalı, 46040, Kahramanmaraş-Türkiye, E-mail: eminederyaister@ksu.edu.tr 


\section{Giriş}

Öğrencilerin eleştirel düşünme, yaratıcıllı, problem çözme, iş birliği yapabilme ve iletişim kurma gibi meta-bilişsel becerilerini geliştirmeleri günümüzde çok önemlidir. ${ }^{1}$ Gerçek olaylardan yola çıkılarak ya da gerçeğe benzetilerek geliştirilen bir anlatım olan vakaya dayalı ögrenme (VDÖ) tekniği, öğrencilere yaparak ve uygulayarak öğrenme firsat1 sağlamaktadır. VDÖ öğrencilerin gerçek yaşamla ilişkili vakalar üzerinde iş birliğine dayalı öğrenme yöntemi ile çalışarak bilgiyi kalıcı bir şekilde öğrendiği, birlikte çalışma, problem çözme ve olaylara çok yönlü bakabilme gibi üst düzey düşünme becerilerinin geliştirildiği bir yaklaşımdır. ${ }^{2-10}$ VDÖ tekniği ilk kez 1908 yllında Harvard Üniversitesi Ticaret Okulu'nda uygulanmıştır. ${ }^{11,12}$ İlerleyen süreçte VDÖ tekniği tıptan mühendisliğe, öğretmen eğitiminden hemşirelik eğitimine kadar uygulamalı birçok farklı disiplinde kullanılmıştır. ${ }^{5}$ VDÖ tekniğinde vakalar; gerekli bilgi ve kuramların kazanılmasını sağlama ve öğrencilerin analiz, çıkarım yapma ve problem çözme alanlarında pratik yapmaları için firsat verme amaçlarıyla kullanılmaktadır., ${ }^{413}$ Vakalar, VDÖ tekniğinin merkezinde yer almaktadır. VDÖ tekniğinin en önemli özelliklerinden biri, öğrencilerin vakalar üzerinden ihtiyaç duydukları bilgiye ulaşma çabası içerisinde olmalarıdır. Bilginin öğrenilmesinde en etkili yollardan biri öğrencinin problem çözme süreci ile beraber bilgi kazanmasıdır. ${ }^{14}$ Bilginin problem çözme sürecinin bir parçası olarak öğrenilmesi sayesinde öğrenci, bilgiyi kullanma yolunu ve bilginin elde edilmesinin nedenlerini de görme firsatı elde etmiş olur. VDÖ tekniği, problem çözme ve düşünme becerilerinin geliştirilmesinde öğrenciye mükemmel firsatlar sağlar. ${ }^{12}$ VDÖ tekniği iş birliğine dayanmaktadır. $\mathrm{Bu}$ nedenle küçük gruplarda uygulandığında; bilişsel becerileri kazandırmasının yanı sıra sosyal becerilerin ve birlikte çalışma alışkanlıklarının gelişmesine de katkı sunmaktadır. ${ }^{9}$

Hemşirelik eğitiminde teori ve klinik uygulama entegre bir şekilde yürütülmekte ve çeşitli öğretim yöntemleriyle bu süreç zenginleştirilmektedir. $^{14}$ VDÖ tekniği öğrencinin teorik bilgi ile uygulamayı birleştirmesine, profesyonel kritik düşünme ve karar verme becerilerini geliştirmesine ve özgüvenlerinin yükseltilmesine olanak sağlamaktadır. ${ }^{9}$ Birçok disiplinde VDÖ tekniğinin etkinliğini gösteren çok sayıda çalışma bulunmasına rağmen hemşirelik alanında yapılan çalışmalar yetersizdir. ${ }^{5}$ Hemşirelik öğrencilerinde mesleki becerilerin geliştirilmesinde öğretim yöntem ve tekniklerinin rolünü araştırmak kaçınılmaz bir ihtiyaç Olarak karşımıza çıkmaktadır. Mesleki beceriler doğal seyirde gelişimsel olduklarından, eğitim programları bu becerilerin kazanılmasında aktif rol oynayabilir. $\mathrm{Bu}$ araştırmanın amacı VDÖ tekniği doğrultusunda planlanan Cerrahi Hastalıkları Hemşireliği dersinde hemşirelik öğrencilerinin vaka sunumları öncesi VDÖ tekniğine yönelik görüşlerinin belirlenmesidir.

\section{Gereç ve Yöntem}

\section{Araştırmanın tipi}

Araştırma, VDÖ tekniği doğrultusunda planlanan Cerrahi Hastalıkları Hemşireliği dersinde vaka sunumları öncesi, hemşirelik öğrencilerinin VDÖ tekniğine yönelik görüşlerinin belirlenmesi amacı ile nitel araştırma yöntemi ile gerçekleştirilmiştir. $\mathrm{Bu}$ araştırmada nitel araştırmalarda sıklıkla kullanılan odak grup görüş̧e tekniği kullanılmıştır. Odak grup görüşmesinin veri toplama tekniği olarak tercih edilme nedeni zengin ve derinlikli veri elde etme imkânı sağlamasıdır. $\mathrm{Bu}$ özelliğine ek olarak etkileşime açı bir ortamda öğrencilerin görüşlerini bütünlüklü olarak sunabilmesi, süreci farklı biçimlerde deneyimleyen öğrencilerin anlatımlarına bütünlüklü bir biçimde ulaşııması, zaman açısından ekonomik olması nedenleriyle de tercih edilmiş̧ir. ${ }^{16,17}$ Odak grup görüşmelerinde amaç, belirlenen bir konu hakkında katıılımcıların bakış açılarına, yaşantılarına, ilgilerine, deneyimlerine, eğilimlerine, düşüncelerine, algılarına, duygularına, tutum ve alışkanlıklarına dair derinlemesine, detaylı ve çok boyutlu nitel bilgi edinmektir. ${ }^{19-23}$

\section{Araştırmanın evreni ve örneklemi}


Araştırma bir devlet Üniversitesi'nin Sağlık Yüksekokulu'nda 12 Şubat 2018-9 Mart 2018 tarihleri arasında yapılmıştır. Araştırmanın örneklemini Cerrahi Hastalıkları Hemşireliği dersini alan ve cerrahi kliniklerinde uygulamaya çıkan tüm 2. sınıf öğrencileri $(n=91)$ oluşturmuştur. Odak grup görüşmesinde grupların, benzer tecrübelere sahip 6-10 kişiden oluşması önerilmektedir. Öğrenciler sistematik örnekleme yöntemi kullanılarak 13 gruba ayrılmış ve her grup 7 ögrenciden oluşmuştur. Cerrahi hastalıkları hemşireliği ders kayıt listesi kullanılarak gruplar sistematik şekilde oluşturulmuştur. $\mathrm{Bu}$ araştırmada öğrencilerin yaş ortalaması $19.36 \pm 1.20$ olup, \% 62'si k1z ögrencidir. Her bir öğrenci grubuyla VDÖ deneyimi öncesi görüşmeler yapılmış olup, görüşme içerikleri raporlanmıştır.

\section{Veri toplama araçları}

Veriler; vaka sunumu deneyimi öncesi yarı yapılandırılmış görüşme formları kullanılarak odak grup görüşmeleri ile toplanmıştır. Görüşme soruları hazırlanmadan önce, araştırma konusu ile ilgili literatür taraması yapılmış, konuyla ilgili kalitatif ve kantitatif araştırmalardan yararlanılmıştır. ${ }^{4-8,10,11,23-25}$ Veri toplamaya başlamadan önce sorulara ilişkin Eğitim Programları ve Öğretim Anabilim Dalı'nda görev yapan 2 Öğretim Üyesi ve Cerrahi Hastalıkları Hemşireliği Anabilim Dalı'nda görev yapan 3 Öğretim Üyesi olmak üzere 5 uzmandan görüş alınmış ve öneriler doğrultusunda sorular yeniden düzenlenerek son şekli verilmiştir. Vaka sunumu deneyimi öncesi yarı yapılandırılmış görüşme formu aşağıda yer alan sorulardan oluşmuştur.

- Vaka sunumu hakkında neler biliyorsunuz?

- Vaka sunumu hakkında neler öğrenmek istiyorsunuz?

- Daha önce katıldığınız grup çalışmalarında yaşadığınız kolaylıklar nelerdir?

- Daha önce katıldığınız grup çalışmalarında yaşadığınız güçlükler nelerdir?

- Cerrahi Hastalıklar Hemşireliği uygulamasında vaka sunumlarının kullanılması hakkında ne düşünüyorsunuz?

- İyi bir vaka sunumu sizce nasil olmalı?

Araştırmanın verileri fiziki koşulları uygun olan ve gruptaki tüm katılımcıların birbirini görüp duyabileceği bir görüşme odasında toplanmıştır. Veri toplama sürecinde; yarı yapılandırılmış görüşme, ses kayıt cihazı, (raportör, grup üyeleri, kolaylaştırıcı ve moderatör için) ve not defteri kullanılmıştır. Her grup ile bir kez odak grup görüşmesi yapılmış, her görüşme ortalama 78 dakika (min.60-max. 90) sürmüş̧ür. $\mathrm{Bu}$ araştırmada araştırma sürecinin geçerlilik ve güvenirliliği;

- Görüşme kayıtlarında değişiklik yapmadan aynen yazıya geçirerek ve saklayarak,

- Veri setini, yüz yüze görüşme tekniğiyle görüşülen kişilerle paylaşarak,

- Yorum katmadan doğrudan alıntılar kullanarak,

- Görüşme kayıtlarında öğrenci ve araştırmacı teyidi sağlayarak,

- Araştırmanın desenini, katılımcılarını, veri toplama araçlarının geliştirilmesini, verilerin toplanmasını, verilerin analizini ve yorumlanmasını ayrıntılı betimleyerek nitel bulguların geçerlik ve güvenirliği sağlanmıştır.

\section{Verilerin analizi}

Nitel veri analizi, araştırmacının verileri düzenlediği, kategorilere ayırdığı, sentezlediği, örüntü ortaya çıkardığı, önemli değişkenleri keşfettiği ve hangi bilgileri rapora yansıtacağına karar verdiği süreç olarak tanımlanmaktadır. ${ }^{26}$ Görüşmelerden elde edilen verilerin analizinde betimsel analiz kullanılmıştır. Betimsel analiz için verilerin tamamı incelenerek kodlar belirlenmiş ve kodlar üzerinden temalar oluşturulmuştur. Belirlenen kodlar ve temalara göre veriler yeniden ele alınarak betimlenmiştir. Nitel araştırmalarda sıklıkla tercih edilen ve mevcut çalışma için betimsel analizde elde edilen veriler, daha önceden belirlenen kavramsal çerçeve veya temalara göre kategorize edilmiş ve bireylerin görüşlerini çarpıcı bir biçimde yansıtmak amaciyla doğrudan alıntılara yer verilmiştir. $^{26,27} \mathrm{Bu}$ doğrultuda veri analizi 
aşaması tümevarımsal analiz bakış açısıyla analize hazırlık ve analiz aşaması olmak üzere iki aşamada gerçekleştirilmiş̧ir. Verilerin çözümlenmesi aşamasında görüşmelerin ses kayıtları dinlenerek elde edilen veriler öncelikle Microsoft Word programı ile yazıya geçirilmiştir. Analize hazırlık aşamasında kayıtların birebir dökümü ardından belirlenen kodların betimsel indekslere yerleştirilmesi gerçekleştirilmiştir. Analiz aşamasında ise uzlaşma çalışmaları sonrası temalar belirlenmiştir. Betimsel analizi yapan birinci yazar belirlediği tema ve alt temaları karşılaştırarak kontrol etmiştir. Son adımda ise; araştırmanın ikinci yazarı, bir bağımsız araştırmacının uzlaşamadığ temaları gözden geçirerek araştırmanın tüm tema ve alt temaları hakkında uzman görüşü vermiştir. Araştırmacılar analiz sonunda tüm tema ve alt temalar konusunda fikir birliğine varmıştır.

\section{Araştırmanın etik boyutu}

Araştırmanın yapılabilmesi için çalışma öncesinde bir üniversitenin Girişimsel Olmayan Klinik Araştırmalar Etik Kurulu'ndan (2018/3-21 karar no'lu), bir Üniversite'nin Sağlı Yüksekokulu Müdürlüğ̈̈'nden ve Hemşirelik Bölüm Başkanlığı'ndan yazılı izin ve odak grup görüşmesi yapılan tüm öğrencilerden sözlü ve yazılı bilgilendirilmiş onam alınmıştır. Öğrencilere verdikleri bilgilerin yalnızca bilimsel amaçla bu çalışmada kullanılacağı ve üçüncü şahıslarla paylaşılmayacağı bilgisi verilmiştir. Öğrencilere istedikleri zaman çalışmadan ayrılabilecekleri belirtilmiştir.

\section{Bulgular}

Hemşirelik öğrencilerinin VDÖ tekniğine ve VDÖ'nün Cerrahi Hastalıklar Hemşireliği dersinde kullanılmasına ilişkin görüşlerinin belirlenmesi amacıyla yapılan bu araştırmada Ana ve alt temalar; 1) VDÖ Tekniğine İlişkin Bilgi (Hastayı Bir Bütün Olarak Ele Alma, Merak Edilenler), 2) Grup Çalışması Deneyimi (Kolaylaştıranlar, Güçleştirenler), 3) Bir Cerrahi Vakası Sunmak (Avantajlar, Duygu Durum), 4) İyi Bir Vaka Sunumu (Vaka Sunumunun Özellikleri, Vakayı Sunacak Öğrenci, Kaynak Seçimi ve Beklentiler) olarak tanımlanmıştır (Tablo 1).
Tablo 1. Hemşirelik öğrencilerinin VDÖ tekniğine ilişkin görüşleri: Ana ve alt temalar

\begin{tabular}{ll}
\hline Ana Tema & Alt Tema \\
\hline Vaka Sunumuna & Hastayı Bir Bütün \\
İlişkin Bilgi & Olarak Ele Alma \\
& Merak Edilenler \\
\hline Grup Çalışması & Kolaylaştıranlar \\
Deneyimi & Güçleştirenler \\
\hline Bir Cerrahi Vakası & Avantajlar \\
Sunmak & Duygu Durum \\
\hline İyi Bir Vaka & Vaka Sunumunun \\
Sunumu & Özellikleri \\
& Vakayı Sunacak \\
& Öğrenci \\
& Kaynak Seçimi \\
& Beklentiler \\
\hline
\end{tabular}

Tema 1. VDÖ tekniğine iliş kin bilgi

Öğrencilerin VDÖ tekniğine ilişkin bilgileri "Hastayı Bir Bütün Olarak Ele Alma" ve "Merak Edilenler" şeklinde iki alt temayla açıklanmıştır.

\section{Hastayı bir bütün olarak ele alma}

Öğrencilerin yarısından fazlası VDÖ tekniğini, hastayı bir bütün olarak ele alma, etkili bakım verme, hastanın ve hastalığın tüm yönlerini arkadaşlarına etkili sunma olarak belirtmişlerdir. $\mathrm{Bu}$ görüşlerden bir örnek aşağıda verilmiştir.

Bir hastayı bulunduğu durumda ele alarak, hastalı̆̆ına ve o an ki durumuna yönelik bakım verip, en iyi hale getirmeye çalışmak için yapılan uygulamaları, yani Hocam hastalığın tedavisini, hemşirelik bakımını, risklerini, korunmast gereken durumları inceleyip, sunmak...(Grup 1)

\section{Merak Edilenler}

Öğrencilerle yapılan görüşmelerde; ağırlıklı olarak VDÖ tekniğinin içeriğinde neler olmalı, iyi bir vaka çalışması nasıl yapılır, öğretim elemanlarının öğrencilerden beklentileri nelerdir, VDÖ neden yapılır, bize ve hastaya faydaları nelerdir, VDÖ tekniğinde nelere dikkat etmeliyiz, hangi materyalleri kullanmalıyız, sunum içeriği öncelikleri ve süresi, ne kadar bilgi vermeliyiz konularını öğrencilerin merak ettiği belirlenmiştir. Ayrıca, öğrencilerin çoğu vakayı doğru belirleyebilecek miyiz, hastaya yeterli bakım verebilecek miyiz, hazırladığımız programa uyabilecek miyiz, heyecanımızı kontrol edebilecek miyiz ve etkili sunum yapabilecek 
miyiz konularında kaygı yaşadıklarını ifade etmişlerdir. $\mathrm{Bu}$ ifadeler aşağıdaki cümlelerle belirtilmiştir:

...Böyle bir vaka hastanede nasıl bulunacak? Bulabileceğimizden endişeleniyoruz gerçekten. Hastayl seçme kriterlerini belirlemek zor olabilir, doğru hastay seçebilecek miyiz? Vaka sunum içeriğinde neler olmall... Hastayı mı hastalığını mi anlatacă̆ız, İyi bir vaka sunumu nasıl olmall, Hocanin bizden beklentisi nedir gibi bir sürü soru var kafamızda... Sunumun ne kadar süreceği...(Grup 5)

\section{Tema 2. Grup çalışması deneyimi}

Öğrencilerin çoğu daha önce grup çalışmasına katıldığını ancak daha önce vaka sunumu yapmadıklarını; daha önceki grup çalışması deneyimlerinde ise bazı kolaylıklar ve güçlükler yaşadıklarını ifade etmişlerdir. Öğrencilerin önceki deneyimleri Grup Çalışmasını Kolaylaştıranlar ve Grup Çalışmasını Güçleştirenler şeklinde iki alt temayla açıklanmıştır.

\section{Kolaylaştıranlar}

Gruplar görüşmelerde çoğunlukla daha önceki grup çalışmalarında iş bölümü ve beyin firtınası yapmanın, karşılıklı anlayış geliştirilmesinin ve iletişim kurmanın bu süreci kolaylaştırdığını belirtmişlerdir. $\mathrm{Bu}$ görüşlerden bir örnek aşağıda verilmiştir:

...Toplu bir şekilde görevler dăgıtıldı $\breve{g} \imath$ için iş yükünün azalması avantajdır. Farklı fikirlerin bir arada bulunması sonucu çalışma daha kapsaml hale gelmesi avantajl... Herkesin birbirine karşı anlayışl olması ve iletişim kurma kabiliyetinin gelişmesi de çok önemli...(Grup 8)

\section{Güçleştirenler}

Gruplar görüşmelerde çoğunlukla daha önceki grup çalışmalarında grup üyelerini bir araya toplamanın zor olduğunu, görev dağılımının adaletsiz yapılmasının, görevini/sorumluluklarını yerine getirmeyen grup üyelerinin varlığının, iletişim problemlerinin ve bireysel anlaşmazlıkların bu süreci güçleştirdiğini belirtmişlerdir. $\mathrm{Bu}$ görüşlerden birkaç örnek aşağıda verilmiştir:
Herkesi bir araya toplamak en büyük problem, birliğ $i$ sağlayamamak, dăğlımı yapmak... Sorumluluklarını yerine getirmeyenler olabiliyor. $B u$ bütünlüğ̈̈ sağlayamamak, adil bir görev dağılımı yapamamak.( Grup 7)

Işs bölümünün eşit bir şekilde yapılmaması ve bazl grup üyelerinin aldı $\breve{g}$ görevi yeterince ve zamaninda yerine getirememesi, toplantılara katılmamasi da var. Bazı grup üyelerinin sorumluluk almak istememesi (konuyu anlatma vb.)... Grup üyelerinden birinin kendini ön plana çıkarmaya çalışması... Bunlar hep zorlaştırıyor.(Grup 5)

\section{Tema 3. Bir cerrahi vakası sunmak}

Grupların çoğu Cerrahi Hastalıklar Hemşireliği uygulamasında vaka sunumlarının yer almasının avantajları ve dezavantajları olacağını belirtmişlerdir. $\mathrm{Bu}$ konu Avantajlar ve Duygu Durum başlıkları altında iki alt temayla açıklanmıştır.

\section{Avantajlar}

Gruplar görüşmelerde çoğunlukla teorik bilginin uygulamaya aktarılmasıyla akılda daha kalıcı olacağını, cerrahi hastalık ve hastasına özgü bilginin pekiştirileceğini, hemşirelik bakımının öneminin kavranacağını, tecrübe kazanacaklarını, araştırma yönlerinin güçleneceğini, özgüvenlerinin artacağını ve sahne korkusunun yenileceğini bu sürecin avantajları olarak öngördüklerini ifade etmişlerdir. Bu görüşlerden bir örnek aşağıda verilmiştir:

Olması güzel bir uygulama, hastalığın tedavisinde hemşirelik bakımı olmazsa olmazdir... Hastalık ve hasta hakkında detaylı bilgiye sahip olunur, hasta ve hastalığa yaklaşım hakkında bilgi edinilir, deneyim kazanırız. Vakaya uygun girişimler planlamak ve sunmak konusunda kolaylık sağlar bence, bakımda hatalarımızı gösterir...(Grup 1)

\section{Duygu durum}

Grupların bazıları görüşmelerde vaka sunumu sürecini bilmemeyi, yapılacak vaka sunumunun beklenilen düzeyde olmaması ve hocaların sorularını yanıtlayamama 
ihtimalinin olduğunu, Cerrahi Hastalıkları Hemşireliği ana derslerden biri olduğu için tedirgin olduklarını, doğru hasta seçme konusunda zorlanabileceklerini ve tüm bu nedenlerin heyecan, korku, kaygı ve anksiyete yarattığını açıklamışlardır. Bu görüşlerden bir örnek aşağıda verilmiştir:

...Süreci bilmediğimiz için şu an zor geliyor aslında vaka sunumlarl hakkında yeterli bilgiye sahip olmadığımı için önyargilı davraniyoruz, bu da bizde stres yaratıyor bununla birlikte kaygımiz artiyor. ...Hasta seçmede zorlanabileceğimizi düşünüyoruz.(Grup 6)

\section{Tema 4. İyi bir vaka sunumu}

İyi Bir Vaka Sunumu temasında grupların çoğu hazırlanacak vaka sunumunun özellikleri ve bunu yapacak öğrencinin sahip olması gereken özellikler, kaynak seçimi ve beklentilerden bahsederek bu tema dört alt temayla açıklanmıştır.

\section{Vaka sunumunun özellikleri}

Görüşmelerde grupların çoğu, hazırlanacak vaka sunumunun hastayı ve hastalığı tüm yönleriyle ele alan, görsel ve işitsel materyallerle desteklenmiş; geniş kapsamlı araştırmalar, açık ve yalın bir dil ve akıcılık içermesi gerektiğini rapor etmişlerdir. $\mathrm{Bu}$ konudaki örnek grup görüşleri aşağıda yer almaktadır:

...Kapsaml olmall, dil etkin bir şekilde kullanılmal, hasta hakkında derin bir anamnez alınmall, o hastallk hakkında derin bir bilgiye sahip olunmal, grup üyeleri arasında uyum olmall, bilgiler sağlam kaynaktan alınmalı. Tanılar eksiksiz ve doğru stralanmalı. ...Ayrica vaka tam anlamiyla araştırılmalı ve sunum yaptığımı kişilere doğru bir şekilde bilgileri aktarmaliyız. Uygun hemşirelik tanılarının konulduğu ve bunlara uygun girişimlerin hastaya doğru bir şekilde uygulandiğl, gelişebilecek komplikasyonların önceden öngörüldüğ̈̈ bir sunum olmall.(Grup 2)

\section{Vakayı sunacak öğrenci}

Görüşmelerde grupların çoğu, iyi bir vaka sunumu yapabilmek için vaka sunumu yapacak öğrencinin kendini ifade etmesini bilen, anlatacağı konunun tüm yönlerine hakim, bakım planında başarılı, yeterli bilgi birikimine sahip, donanımlı, araştırmacı, özgüvenli, diksiyonu düzgün ve iletişiminin iyi olması gerektiğini rapor etmişlerdir. $\mathrm{Bu}$ konudaki örnek grup görüşleri aşağıda ifade edilmiştir:

...Yeterli bilgi donanimina sahip, araştırma ruhuna sahip, iletişim becerisi gelişmiş, düşüncelerini rahatlıkla dile getirebilen, empati yapabilmeli, NANDA' nin Hemşirelik Tanılarl'na vakıf olmalı ve hangi tanıyı niçin koyduğunu bilmeli.(Grup 3)

\section{Kaynak seçimi}

Görüşmelerde grupların bir kısmı, iyi bir vaka sunumu için çokça kaynağa ihtiyaç olduğunu; internet ve kütüphane kaynakları, bu konuda uzman kişiler (uygulama hocaları), tecrübe etmiş kişiler (vaka sunumu yapan öğrenci/hemşire), Hemşirelik tanıları kitapları, makaleler, hasta dosyaları, hastane kayıtları, hasta anamnezi, hasta yakınlarının ifadeleri, Cerrahi Hastalıklar Hemşireliği kitapları ve ders notlarının bu konuda çok yarar sağlayacağını rapor etmişlerdir. $\mathrm{Bu}$ konudaki örnek grup görüşleri aşağıda yer almaktadır:

...Hastanın kendisi, yakınlarl, dosyası, hemşiresi ve doktorundan da bilgi toplanmall. Nanda hemşirelik tanilarl kitabindan bilgi ayrica. Makalelerden, Cerrahi hemşirelik kitabı da burada çok önemli. Anlayacağınız çok kaynak lazım çooookkkkk...( Grup 11)

\section{Beklentiler}

İyi bir vaka sunumuna dair grupların bazıları görüşmelerde vakadan (hastadan), bazıları grup üyelerinden ve bazıları katılımcilardan beklentileri olduklarını ve bunun bu süreç için önemli olduğunu da vurgulamışlardır. Bunu bazı gruplar aşağıdaki görüşlerinde belirtmiştir:

... Burada hastanin tedaviye ve sorulara katılım sağlaması, doğru ve eksiksiz bilgiler vermesi, iletişim becerisinin iyi olmasi, kendini iyi tanıması, stajyer hemşirelere güven duyması... ...Hastanın sikıntılarını dile getirebilecek bir bilgi düzeyine sahip olması, yaşadiğı sıkıntıları utanmadan dile 
getirmesi de bu sunumu daha iyi yapar.(Grup 12)

Herkesin tam katılım sağlaması, ödev dağılımının eşit bir şekilde olması ve herkesin sorumluluk üstlenmesi gerekiyor. Verilen sorumluluğu tam olarak yerine getirmesi ve zamaninda teslim etmesi ve grup üyelerinin vaka sunumu yapabilecek yeterli bilgi düzeyine sahip olmasl, kendilerine verilen sorumluluk için geniş araştırmalar yapmast... Gruptaki diğer ekip üyeleriyle uyumlu olmast, anlayışlı olmast...(Grup 5)

...Katılımcllar hata aramamalı, düzeltmeye yönelik olmall düşünceleri $k i$ sunum güzelleşsin. Sessiz olunmalı dinlerken ve anlatan kişiye saygll olmall, grup üyelerinin dikkatini dağıtmamalı.( Grup 13)

\section{Tartışma}

VDÖ, öğrencilerin gerçek yaşamla ilişkili vakalar üzerinde iş birliğine dayalı öğrenme yöntemi ile çalışarak bilgiyi kalıcı bir şekilde öğrendiği, birlikte çalışma, problem çözme ve olaylara çok yönlü bakabilme gibi üst düzey düşünme becerilerinin geliştiği bir yaklaşımdır. ${ }^{2-10} \mathrm{Bu}$ araştırmanın amacı VDÖ tekniği doğrultusunda planlanan Cerrahi Hastalıkları Hemşireliği dersinde vaka sunumları öncesi, hemşirelik öğrencilerinin VDÖ tekniğine ve Cerrahi Hastalıklar Hemşireliği dersinde kullanılmasına ilişkin görüşlerini niteliksel araştırma yöntemleri ile ortaya koymaktır. Bu araştırmada örneklem grubundaki 91 hemşirelik öğrencisi 13 gruba ayrılmış ve her bir grup 7 öğrenciden oluşmuştur.

$\mathrm{Bu}$ araştırmada öğrencilerin Cerrahi Hastalıkları Hemşireliği dersi ile ilişkili vaka çalışmaları öncesinde ağırlıklı olarak; VDÖ tekniği içeriğinde neler olmalı, iyi bir vaka çalışması nasıl yapılır, öğretim elemanlarının beklentileri nelerdir, vaka çalışması neden yapılır, bize ve hastaya faydaları nelerdir, nelere dikkat etmeliyiz, hangi materyalleri kullanmalıyız, vaka çalışmasının sunum içeriği, öncelikleri ve süresi, hastalara ne kadar bilgi vermeliyiz konularında kaygı yaşadıkları ortaya çıkmıştır. Ayrıca bu araştırmada öğrenciler VDÖ deneyimi öncesi; vaka çalışmalarını sunmanın, kendilerinde heyecan, korku, kaygı, anksiyete ve stres yarattığını ifade etmişlerdir. Baysan Arabacı ve arkadaşlarının hemşirelik birinci sınıf öğrencilerinin ilk klinik deneyim öncesi, sırası ve sonrası anksiyete ve stres düzeylerini değerlendirmek amacıyla yaptıkları çalışmada, öğrencilerin \%69.1'inin heyecan, \%40.4'ünün kayg1, \%33.0'inın stres, $\% 28.7$ 'sinin korku ve \%21.3'ünün gerginlik yaşadığı saptanmıştır. ${ }^{28}$

Öğrencilerin çoğu daha önce grup çalışmasına katıldığını ancak daha önce vaka sunumu yapmadıklarını; daha önceki grup çalışması deneyimlerinde ise bazı kolaylıklar ve güçlükler yaşadıklarını belirtmektedirler. Öğrencilere göre iş bölümü ve beyin firtınası yapma, karşılıklı anlayış geliştirme ve etkili iletişim kurma grup çalışmasını kolaylaştıran etmenlerdir. Grup üyelerini bir araya toplamanın zorluğu, görev dağılımının adaletsiz yapılması, görevini/sorumluluklarını yerine getirmeyen grup üyelerinin varlığ iletişim problemleri ve bireysel anlaşmazlıklar ise süreci güçleştiren etmelerdir. VDÖ'nün en önemli özelliklerinden biri vakaların çözümünde grupla çalışma ortamları sunarak öğrencilerin hem birlikte ögrrenmelerine hem de sosyal özelliklerinin gelişmesine yardımcı olacak firsatlar sunmasıdır. Dupuis ve Persky geleneksel yöntemlere göre VDÖ'nün öğrencilerin iletişim becerilerini geliştirmede çok daha etkili olduğunu bildirmektedir. ${ }^{2}$ Benzer şekilde Razzouk VDÖ'nün anlatıma dayalı yönteme nazaran öğrencilerin bireysel olarak dikkat yeteneklerinin gelişmesi, kendilerine güven duymaları ve dersle ilgili memnuniyet duymalarında daha etkili olduğunu ve VDÖ'nün genel olarak daha yüksek öğrenme çıtıtıları oluşturduğunu, daha pozitif davranış kazandırdığını ve grup olarak öğrenmede daha etkili olduğunu ortaya koymuştur. ${ }^{29}$

$\mathrm{Bu}$ araştırmada öğrenciler VDÖ uygulamasıyla bilgiyi birçok kaynaktan elde etmeleri gerektiğini ve bu bilgileri gerçek dünyadaki problemlerle ilişkilendirme firsatı bulacaklarından bilginin daha kalıcı olarak elde edileceğini vurgulamışlardır. Smith bilginin kalıcılığ ve kullanılması noktasında VDÖ'nün üstünlüğü olduğunu belirtmektedir. ${ }^{8}$ VDÖ’nün öğrencilerin bilişsel 
becerilerini geliştirmeye katkısına ilişkin ögrencilerle yapılan görüşmelerde elde edilen bulgulara göre; öğrencilerin VDÖ sürecinde kullanılacak vakalar sayesinde öğrendikleri bilgileri uygulama firsatı bulacakları ve vaka sunumlarının eğitici ve öğretici rolünün bireysel gelişime ve hemşire olma sürecine katkı sağlayacağını düşünmektedir. Ciraj ve arkadaşlarının eğiticilerin ve öğrencilerin VDÖ’ye ilişkin görüşlerini değerlendirdiği çalışmalarında eğiticiler; VDÖ'nün öğrencilerin derse olan ilgilerini arttırmada ve özellikle mikrobiyoloji alan bilgisinin kalıcılığının sağlanmasında etkili olduğunu belirtmişlerdir. ${ }^{30}$ Waliany ve arkadaşları VDÖ'nün tıp öğrencilerinin raporlama, yönetim, hasta eğitimi ve yorumlama becerilerini geliştirdiğini bildirmektedir. ${ }^{31}$ Peiman ve arkadaşları tarafından İran'da tıp öğrencileriyle yapılan çalışmada, öğrencilerin büyük kısmı VDÖ tekniğinin öğrenme üzerinde pozitif katkısı olduğu görüşündedir. ${ }^{32}$ VDÖ'nün hem eğitici hem de öğrenci açısından yararlarını gösteren çalışmalara paralel bu araştırmada özellikle öğrencilerin hemşire olma sürecine VDÖ'nün katkı sağlayacağını ifade etmeleri mesleki eğitim açısından önemlidir.

Gruplar VDÖ uygulaması öncesi görüşmelerde çoğunlukla hazırlanacak bir vaka sunumu için ayrıntılı bir anamnez, hastanın ihtiyaçları doğrultusunda planlanan hemşirelik bakımı, görsel ve işitsel materyallerle desteklenmiş etkili bir sunum ve grubun vakaya hakim olması gerektiğini rapor etmişlerdir. İyi bir vaka sunumu yapabilmek için vaka sunumu yapacak öğrencinin; sunum hazırlama becerisi olan, konuya hakim, iletişim becerileri gelişmiş, hastayı doğru değerlendiren, NANDA'y1 etkili kullanabilen, araştırmacı, anlatacağı konunun tüm yönlerine hakim, klinik uygulamada başarılı, yeterli bilgi birikimine sahip, özgüvenli, diksiyonu düzgün olması ve katılımcılarla göz teması kurması gerektiğini belirtmişlerdir. Yoo ve Park yeni mezun çalışan hemşirelerde VDÖ ile klasik öğretim tekniğinin (ders tabanlı eğitim) problem çözme becerileri üzerine etkisini değerlendirmek amacıyla yaptıkları çalışmada VDÖ ile eğitim alan hemşirelerin objektif ve subjektif problem çözme becerilerinin klasik öğretim tekniği ile eğitim alanlara göre daha yüksek olduğu sonucuna varılmıştır. ${ }^{10}$ Aynı zamanda VDÖ temel bilimler ile klinik alanın bütünleşmesine katkı sağlayabilir. Nitekim Peiman ve arkadaşları tıp eğitimi için VDÖ, temel bilimler ve klinik bilimlerin bütünleştirilmesinde bir yol olarak atfetmişlerdir. ${ }^{32}$

\section{Sonuç}

$\mathrm{Bu}$ çalışmada öğrenciler, daha önce VDÖ tekniğini deneyimlememiş olmalarının heyecan, korku ve kaygı yaşamalarına neden olduğunu ve vakayı (hastayı) bir bütün olarak ele almak gerektiğini böylece bilginin daha kalıcı olarak elde edileceğini ve bu sürecin onları hemşirelik mesleğine hazırlayacağını ifade etmişlerdir. Öğretim elemanları VDÖ sürecinde öğrencilerin duygu durumunu ve öğrenciler tarafından deneyimlenen olumsuz duyguları değerlendirmeli ve bu duyguları öğrencilerin kontrol etmesini kolaylaştırmalıdır. Ayrıca hemşirelik alanında vaka sunumuna dayalı öğretim tekniklerini içeren çalışma sayısı oldukça kısıtlıdır. McLean tarafından yapılan geniş kapsamlı literatür taramasında sağlı disiplinleriyle ilişkili vaka temelli 70 çalışmanın olduğu ve bu çalışmaların sadece üçünün hemşirelik alanında yapıldığı bildirilmektedir. ${ }^{7} \quad \mathrm{Bu}$ bağlamda VDÖ'nün hemşirelik bölümünün uygulamalı derslerinde öğretim tekniği olarak kullanılması ve hemşirelik eğitiminde VDÖ tekniği kullanımına ilişkin öğrenci deneyimlerinin irdelenmesi önerilmektedir.

\section{Araştırmanın Etik Boyutu}

Araştırmanın yürütülebilmesi için gerekli bir üniversitenin Girişimsel Olmayan Klinik Araştırmalar Etik Kurulu'ndan (2018/3-21 karar no'lu), bir Üniversite'nin Sağl1k Yüksekokulu Müdürlüğü'nden ve Hemşirelik Bölüm Başkanlığı'ndan yazılı izin alınmıştır.

\section{Bilgilendirilmiş Onam}

Araştırmaya katılmaya gönüllü öğrencilere araştırmanın amacı açıklanarak onamları alınmıştır.

\section{Yazar Katkıları}

Çalışma konsepti/Tasarımı:YA; Veri toplama:YA, EDİ; Veri analizi ve 
yorumlama:YA, EDİ; Yazı taslağı:YA; İçeriğin eleştirel incelenmesi:YA, EDİ; Son onay ve sorumluluk:YA, EDİ; Teknik ve malzeme desteği:YA, EDİ; Süpervizyon:YA.

\section{Teşekkürler}

Araştırmanın yapılmasına katkıda bulanan hemşirelik öğrencilerine teşekkür ederiz.

\section{Çıkar Çatışması Beyanı}

Yazarlar arasında herhangi bir çıkar çatışması bulunmamaktadır.

\section{Araştırma Desteği}

$\mathrm{Bu}$ çalışmada herhangi bir fon veya destekten yararlanılmamıştır.

\section{Hakem Değerlendirmesi}

Diş bağımsı.

\section{Kaynaklar}

1. Carl A, Strydom S. e-Portfolio as reflection tool during teaching practice: The interplay between contextual and dispositional variables. South African Journal of Education. 2017;37(1):1-10.

2. Dupuis RE, Persky AM. Use of case-based learning in a clinical pharmacokinetics course. Am J Pharm Educ.2008;72(2):1-7.

3. Ertmer PA, Newby TJ, Macdougall M. Students' responses and approaches to case-based instruction: The role of reflective selfregulation. Am. Educ. Res. J. 1996;33(3):719-752.

4. Kaptı SB. Vak'aya dayalı öğretim programının etkililiği [Doktora Tezi]. Ankara: Hacettepe Üniversitesi; 2014.

5. Majeed F. Effectiveness of case-based teaching of physiology for nursing students. J Taibah Univ Med Sci. 2014;9(4):289292.

6. Mclean SF. Case-based learning and its application in medical and health-care fields: A review of worldwide Literature. $\mathrm{J} \mathrm{Med}$ Educ Curric Dev. 2016;3:39-49.

7. Noohi E, Karimi-Noghondar M, Haghdoost A. Survey of critical thinking and clinical decision making in nursing student of Kerman University. Iran $J$ Nurs Midwifery Res. 2012;17:440-444.

8. Smith G. The use and effectiveness of the case study method in management education- a critical review. Management Education and Development. 1987;18(1):51-61. https://doi.org/10.1177/135050768701800107

9. Thistlethwaite JE, Davies D, Ekeocha S, Kidd JM, MacDougall $\mathrm{C}$, Matthews P, et al. The effectiveness of case-based learning in health professional education. A BEME systematic review: BEME guide No. 23. Med Teach. 2012;34(6):e421-44. doi: 10.3109/0142159X.2012.680939.

10. Yoo M-S, Park J-H. Effect of case-based learning on the development of graduate nurses problem-solving ability. Nurse Educ. Today. 2014;34(1):47-51.

11. Mcwilliam PJ. The Case Method of Instruction. Journal of Early Intervention. 1992;16(4):360-373. doi.org/10.1177/105381519201600407

12. Elksnin LK. Use of the Case Method of Instruction in Special Education Teacher Preparation Programs: A Preliminary Investigation. Teacher Education and Special Education. 1998;21(2):95-108. https://doi.org/10.1177/088840649802100204

13. Merseth KK. Cases, Case Methods, and the Professional Development of Educators. Place of publication not identified: Distributed by ERIC Clearinghouse; 1994.

14. Tyler RW. Basic principles of curriculum and instruction. Chicago: University of Chicago. Press, 1949.
15. Ordin YS, Bilik Ö, Turhan Damar H, Çelik B. Cerrahi kliniklerdeki hemşirelik öğrencilerinin yansıtma raporlarından elde edilen öğrenme deneyimleri. ENAD. 2018;6(3):106-120. DOI:10.14689/issn.2148-2624.1.6c3s5m

16. Kırca Ali-İftar G. Odak grup görüşme tekniği. Özel Eğitim Dergisi. 2004;14(2):7-24.

17. Çokluk Ö, Yılmaz K, Oğuz E. Nitel bir görüşme yöntemi: Odak grup görüşmesi. Kuramsal Egitimbilim. 2011;4 (1):95-107.

18. Patton MQ, Schwandt TA. Qualitative Research \& Evaluation Methods: Integrating Theory and Practice. Thousand Oaks, CA: Sage; 2015.

19. Bowling Ann. Research methods in health: investigating health and health services. 4th edition. Maidenhead: McGraw Hill Open University Press; 2014.

20. Kitzinger J. The methodology of Focus Groups: the importance of interaction between research participants. Sociology of Health and Illness. 1994;16(1):103-121.

21. Krueger RA. Focus groups a practical guide for applied research. 2nd ed. San Diego, CA, Sage Publications; 1994.

22. Gibbs A. Focus groups. Social research update 19. department of sociology, university of surrey, surrey, UK; 1997. http://www.soc.surrey.ac.uk/sru/SRU19.html

23. Bowe CM, Voss J, Aretz HT. Case method teaching: An effective approach to integrate the basic and clinical sciences in the preclinical medical curriculum. Medical Teacher. 2009;31(9):834-841. DOI: 10.1080/01421590902922904

24. Brooke SL. Using the case method to teach online clasess: Promoting socratic dialouge and critical thinking skills. International Journal of Teaching and Learning in Higher Education. 2006;18(2):142-149.

25. Williams B. Case based learning--a review of the literature: is there scope for this educational paradigm in prehospital education? Emerg Med J. 2005;22(8):577-581. doi: 10.1136/emj.2004.022707

26. Denzin NK, Lincoln YS. Handbook of qualitative Research. 2nd ed. London: Sage Publications; 2000.

27. YıldırımA, Şimşek H. Sosyal bilimlerde nitel araştırma yöntemleri. 6.Baskı. Ankara: Seçkin Yayınları; 2013.

28. Baysan Arabacı L, Akın Korhan E, Tokem Y, Torun R. Hemşirelik birinci sınıf öğrencilerinin ilk klinik deneyim öncesi-sırası ve sonrası anksiyete ve stres düzeyleri ve etkileyen faktörler. Hacettepe Üniversitesi Hemşirelik Fakültesi Dergisi. 2015:1-16.

29. Razzouk R. The effects of case studies on individual learning outcomes, attitudes toward instruction, and team shared mental models in a team-based learning environment in an undergraduate educational psychology course [PhD thesis]. Florida: Florida State University; 2011.

30. Ciraj AM, Vinod P, Ramnarayan K. Enhancing active learning in microbiology through case based learning: experiences from an Indian medical school. Indian J. Pathol. Microbiol. 2010; 53: $729-733$.

31. Waliany S, Caceres W, Merrell SB, Thadaney S, Johnstone N,Osterberg L. Preclinical curriculum of prospective casebased teaching with faculty- and student-blinded approach. BMC Medical Education. 2019;19(1):1-12. doi.org/10.1186/s12909-019-1453-x

32. Peiman S, Mirzazadeh A, Alizadeh M, Mortaz Hejri S, Najafi MT,Tafakhori A, et al. A case based-shared teaching approach in undergraduate medical curriculum: A way for integration in basic and clinical sciences. Acta Med Iran. 2017;55(4):259-64. 